\title{
ТРУДОВАЯ МИГРАЦИЯ В РОССИИ В ПЕРИОД КОРОНАВИРУСНОЙ ПАНДЕМИИ
}

\author{
МИХАИЛ ДЕНИСЕНКО, ВЛАДИМИР МУКОМЕЛЬ
}

\begin{abstract}
Введение карантинных мер в связи с пандемией коронавируса сопровождалось перекрытием трансграничных коммуникаций и ограничением деятельности предприятий в большинстве отраслей экономики. Трудовые мигранты и члены их семей, пребывающие на территории России, оказались 8 сложном положении. Сокращение занятости в первую очередь в тех сферах, где работают мигранты, сделало иностранных граждан одной из наиболее уязвимых социальных групп. Первый пласт вопросов, рассматриваемых в статье, связан с оценкой ситуачии, в которой оказались мигранты, находящиеся в России. В каких видах экономической активности сокрашение занятости стало особенно болезненным для мигрантов? Каково их материальное положение? Насколько они готовы покинуть Россию в случае восстановления транспортных коммуникаций? Каковы их ближайшие и отдаленные планы, связанные с трудовой деятельностью и жизнью в России? Во втором фокусе исследования находятся потенциальные мигранты, которые не смогли въехать в Россию после разрыва международных транспортных связей. Каково их экономическое положение на родине? Как быстро они собираются выехать в Россию в случае снятия ограничений на международные поездки? Каковы их краткосрочные и долгосрочные планы, связанные с пребыванием в России? Поиску ответов на эти вопросы посвящена настоящая статья, базирующаяся на онлайн-опросе 2695 иностранных граждан (в том числе 1304 мигрантов, находящихся на территории России, и 1391 - за ее пределами), а также телефонном опросе 300 трудовых мигрантов в Московском мегаполисе, проведенных в первой половине июня 20202.
\end{abstract}

Ключевые слова: трудовая миграция, мигранты, COVID 19, иностранные работники, онлайн-опрос, САТІ, занятость, миграционные планьл.

Коронавирусная эпидемия ухудшила положение трудовых мигрантов во всех странах мира (ILO 2020; OECD 2020). Россия в этом плане не стала исключением. Введение карантинных мер в марте 2020 г. приостановило частично или полностью деятельность многих предприятий, особенно в тех отраслях, где занято большое число иностранных работников: ресторанный и гостиничный бизнес, клининг, оптовая и розничная торговля, отчасти строительство. Как и российские граждане, часть трудовых мигрантов потеряли работу или перешли на неполный рабочий день, что привело к полной или частичной потере дохода. Следствием этого стало сокращение денежных переводов на родину из России. По данным Центробанка РФ, объем переводов через платежные системы в страны СНГ в апреле 2020 г. был в 1,7 раз меньшим, чем в апреле 2019 г.

МИХАИЛ БОРИСОВИЧ ДЕНИСЕНКо (mdenissenko@hse.ru), НАЦИОНАЛЬНЫЙ ИССЛЕДОВАТЕЛЬСКИЙ УНИВЕРСИТЕТ «ВЫСШАЯ ШКОЛА ЭКОНОМИКИ», РОССИЯ.

ВЛАДИМИР ИЗЯВИч МУКОМЕЛЬ (mukomel@mail.ru), ИНСТИТУТ СОЦИОЛОГИИ ФЕДЕРАЛЬНОГО НАУЧНОИССЛЕДОВАТЕЛЬСКОГО СОЦИОЛОГИЧЕСКОГО ЦЕНТРА РАН, РОССИЯ.

ИНТЕРНЕТ-ОПРОС РЕАЛИЗОВАН ПРИ ПОДДЕРЖКЕ ДИРЕКЦИИ ПО ЭКСПЕРТНО-АНАЛИТИЧЕСКОЙ РАБОТЕ НИУ ВШЭ В РАМКАХ ПРИКЛАДНОГО ПРОЕКТА ЦФИ НИУ ВШЭ ТЗ-125: «СИСТЕМАТИЗАЦИЯ ПУТЕЙ ДОСТИЖЕНИЯ НАЦИОНАЛЬНЫХ ЦЕЛЕЙ В ОБЛАСТИ ОБЕСПЕЧЕНИЯ УСТОЙЧИВОГО ЕСТЕСТВЕННОГО РОСТА ЧИСЛЕННОСТИ НАСЕЛЕНИЯ РОССИЙСКОЙ ФЕДЕРАЦИИ И ПОВЫШЕНИЯ ОЖИДАЕМОЙ ПРОДОЛЖИТЕЛЬНОСТИ ЖИЗНИ ДО 78 ЛЕТ (К 2030 Г. ДО 80 ЛЕТ)». ОПРОС САТІ ПРОВЕДЕН В РАМКАХ ПРОЕКТА ЦФИ НИУ ВШЭ ТЗ-151 «АНАЛИЗ РИСКОВ СОЦИАЛЬНОЙ НАПРЯЖЕННОСТИ И ПРЕДЛОЖЕНИЯ ПО МЕРАМ ПОЛИТИКИ, НАПРАВЛЕННЫМ НА ПОВЫШЕНИЕ СОЦИАЛЬНОЙ устойчивости».

СТАТЬЯ ПОСТУПИЛА В РЕДАКЦИЮ В ИЮЛЕ 2020 Г. 
По оценкам ГУВМ МВД в марте на территории России на законных основаниях работало более 1 млн граждан Узбекистана, около 500 тыс. - Таджикистана, более 350 тыс. - Киргизии (основных стран происхождения трудовых мигрантов). Прекращение в марте транспортного сообщения между государствами не позволило всем желающим вернуться на родину. Всего в России на 1 апреля 2020 г., согласно сведениям из Центрального банка данных по учету иностранных граждан и лиц без гражданства (ЦБДУИГ), находилось 10,2 млн иностранных граждан, включая работников, студентов, туристов и др. Из них 4,2 млн составляли иностранцы, прибывшие в Россию с целью «работа по найму» (Флоринская 2020: 14). С учетом иностранцев, которые имели вид на жительство и разрешение на временное проживание, а также работающих иностранных студентов общая численность иностранных работников в России приближалась к 5 млн человек.

Введенные Правительством РФ с 18 марта ограничения на въезд иностранцев и лиц без гражданства нарушили нормальный ход трудовой миграции, в которой присутствовала четкая сезонная составляющая. Традиционно численность трудовых мигрантов минимальна в январе. С марта, как показывает динамика числа патентов, оформленных работниками из Узбекистана, Таджикистана, Украины, Молдавии и Азербайджана (рисунок 1), их количество быстро увеличивается вместе с увеличивающимся сезонным спросом на рабочую силу. Максимальных значений поток мигрантов достигал в апреле-мае, но в 2020 г. этого не произошло из-за коронавирусной пандемии. Так, количество впервые оформленных патентов в мае было в 3,5 раза меньше, чем в январе. Всего, по данным ГУВД МВД, иностранцев, поставленных на миграционный учет в апреле-июне 2020 г. в связи с работой, было на 1,3 млн человек меньше, чем за тот же период 2019 г.

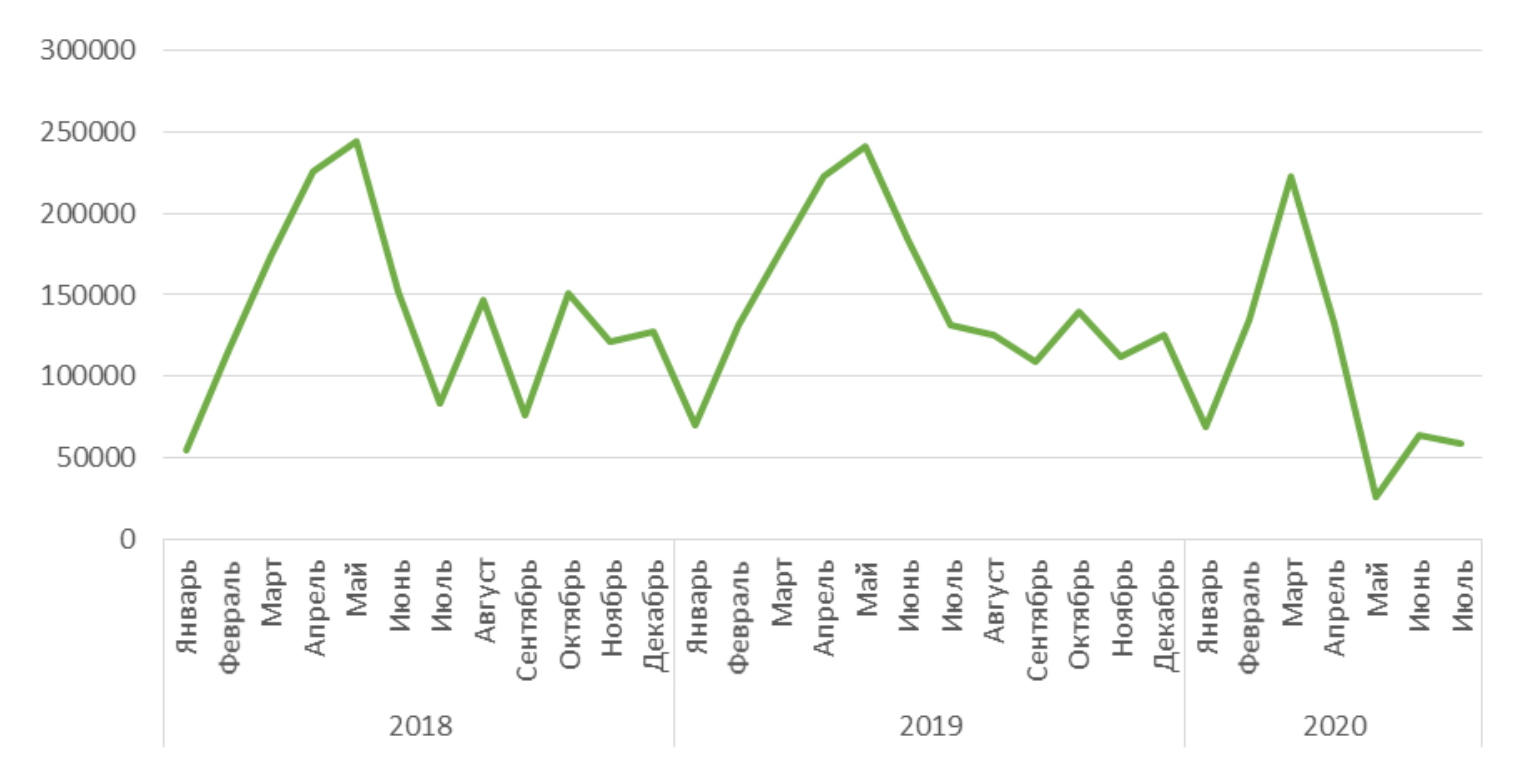

\section{Рисунок 1. Количество оформленных патентов в России с января 2018 по июль 2020 г.}

Источник: (ГУВМ МВД РФ 2020).

Недостаток информации о положении иностранных работников в России в период коронавирусной пандемии породил разного рода домыслы и слухи. Общественное мнение было взбудоражено страшилками массмедиа, предсказывающими рост преступности 
иностранцев, лишенных средств к существованию. Всплеск алармистских настроений пришелся на середину апреля ${ }^{1}$. Эти настроения инициировались, как уже привычно, правоохранителями ${ }^{2}$ и политиками ${ }^{3}$, одиозными личностями из РПЦ4 ${ }^{4}$ националистами а также «экспертами», утверждающими, что «криминальные настроения среди мигрантов более ярко выражены, чем у россиян» (Погребняк 2020), или полагающими, что мигранты в Москве работают за зарплату в 8 тыс. рублей 6 . К ним добавились персоны, позиционирующие себя как представители мигрантов ${ }^{7}$ либо правозащитники. Так, во в целом выдержанном Докладе Московского бюро по правам человека (МБПЧ) «COVID-19: проявления расизма, ксенофобии и миграционные процессы в условиях пандемии» присутствовали непроверенные ссылки на кейсы, где о мигрантах вообще речь не шла ${ }^{8}$, или говорилось о случившемся 3 года назад 9 . Однако на эти кейсы ссылались массмедиа, апеллируя к докладу МБПЧ ${ }^{10}$.

Звучали, конечно, и голоса специалистов (Абашин 2020; Полетаев 2020) ${ }^{11}$. Наиболее афористично их позицию сформулировал Д. Александров: «Рабочие мигранты кажутся мне

\footnotetext{
${ }^{1}$ По данным информационно-аналитической системы «Медиалогия», на неделю с 12 по 20 апреля пришлось $11 \%$ всех публикаций за февраль-июнь 2020 г., посвященных проблемам мигрантов в период пандемии.

${ }^{2}$ См.: Фалалеев М. (2020). Неудобные гости. Коронавирус может вызвать в России рост преступности среди мигрантов. Российская газета, Федеральный выпуск 122(8176), 07.06.2020. URL:

https://rg.ru/2020/06/07/koronavirus-mozhet-vyzvat-v-rossii-rost-prestupnosti-sredi-migrantov.html; Михайлов Михаил (2020). Вирус для мигрантов. Насколько опасен он для всего общества? «Вместе-РФ», 06.05.я 2020. URL: https://vmeste-rf.tv/analytics/virus-for-migrants-how-dangerous-is-it-to-society/

${ }^{3}$ См.: РИА Новости (2020). Жириновский предложил ограничить возвращение в Россию трудовых мигрантов. 23.05.2020. URL: https://ria.ru/20200523/1571877700.html; Вахрушев Алексей (2020). Полпред Цуканов заявил об угрозе из-за бомжей и мигрантов во время эпидемии коронавируса. Ura.ru., 13.04.2020. URL: https://ura.news/news/1052427087

${ }^{4}$ См. Голованов Р. (2020). Отец Димитрий Смирнов: Россия вымрет. И нас заменят мигранты. А русские пойдут в дворники, курьеры и таксисты. КП, 26.04. 2020. URL: https://www.kp.ru/daily/27122.5/4206121/. ${ }^{5}$ См.: Росбалт (2020). Русские наџионалисть призвали выдворить всех мигрантов из Средней Азии, пока кризис не перерос в «криминальную катастрофу». 23.04. 2020. URL:

https://www.rosbalt.ru/russia/2020/04/23/1840030.html

${ }^{6}$ См.: Соколова Е. (2020). Коронавирус вызвал взрыв ксенофобии: мигранты отбирают работу у местных/ Московский Комсомолеи, 20.05.2020; Актуальные комментарии (2020). Пороховая бочка: как коронавирус сказался на мигрантах, 13.05.2020. URL: http://actualcomment.ru/porokhovaya-bochka-kak-koronavirusskazalsya-na-migrantakh-2005131429.html

${ }^{7}$ Президент Федерации мигрантов России Вадим Коженов, начавший стращать взрывным ростом криминала среди мигрантов в первой половине апреля (см.: Стешин Д. (2020). Президент Федерации мигрантов Вадим Коженов «Если безработные мигранты не уедут, рост криминала будет взрывной!» КП., 14.04.2020. URL https://www.kp.ru/daily/27117/4197954/). Спустя несколько дней он признал отсутствие роста преступности мигрантов, но продолжал пугать ею обывателя (см.: Говорит Москва (2020). $B$ Федерации мигрантов не зафиксировали всплеска преступности среди иностранцев в России, . 24.04. 2020. URL: https://govoritmoskva.ru/news/232071/

8 Лента.ру (2020). Грабитель ударил россиянина ножом ради пакета с продуктами, 02.05.2020. URL: https://m.lenta.ru/news/2020/05/02/dikost/?fbclid=IwAR3V2NekwFZ_nivMMyeZpHiryzGPBEYI0oWVCi87AXL ZzDbpij90PH2G6kI

${ }^{9}$ КП (2020). В Воронеже будут судить гастарбайтера, ограбивщего и жестоко избивщего пенсионерку и ее внука, 30.04.2020. URL:

https://www.vrn.kp.ru/online/news/3856774/?utm_source=yxnews\&utm_medium=desktop\&utm_referrer=https $\% 3$ A $\% 2$ F\%2Fyandex.ru\%2Fnews

${ }^{10}$ Компания (2020). В Москве мигранты стали чаще совершать преступления, 12.05.2020.

URL: https://ko.ru/news/v-moskve-migranty-stali-chashche-sovershat-prestupleniya/

${ }^{11}$ См. также: Коммерсанть" (2020). Рассказы о том, что мигранты пойдут грабить немигрантов из-за карантина,— это страшилка, 03.04.2020 . URL: https://www.kommersant.ru/doc/4312764
} 
едва ли не самой безопасной группой населения» ${ }^{12}$. Но здравые голоса тонули в хоре вопиющих о преступности мигрантов. Опровержения московских и федеральных властей о росте криминала мигрантов также не оказали существенного влияния на информационное освещение проблемы ${ }^{13}$; заголовки статей говорят сами за себя ${ }^{\mathbf{1 4}}$. Однако массмедиа ${ }^{15}$ продолжали пугать обывателя вплоть до конца июня грядущим ростом преступлений ${ }^{16}$.

Меньше выделяется тема распространенности коронавируса среди мигрантов, также подаваемая под устрашающими заголовками. Хотя проблема действительно существует и во многом обусловлена тем, что, по словам В. Чупик, «мигранты очень сильно стигматизированы, и поэтому готовы даже скрывать заболевание коронавирусом» ${ }^{17}$. Словами дело не ограничивалось. Еще в феврале представители «видимых меньшинств», особенно выходцы из Китая и Юго-Западной Азии, столкнулись во многих странах мира (США, Франция, Италия и др. - и в России тоже), с дискриминацией не только на бытовом уровне (HRW 2020).

В таких обстоятельствах, связанных с отсутствием объективной информации, позволяющей судить о ситуации, в которой оказались мигранты, сотрудники Института социологии ФНИСЦ РАН и НИУ Высшая школа экономики провели исследование, ориентированное на анализ ситуации с занятостью мигрантов, их материальным положением, готовностью вернуться на родину (или - для находящихся в стране происхождения - приехать в Россию), их краткосрочных и долгосрочных планах относительно работы и пребывания в России.

\section{МЕТОДОЛОГИЯ ИССЛЕДОВАНИЯ И ПРОФИЛИ МИГРАНТОВ}

В рамках исследования в первой половине июня 2020 г. был проведен онлайн-опрос около 8 тыс. иностранных граждан, в подавляющем большинстве граждан стран СНГ. Респонденты должны были отвечать двум условиям: не иметь российского гражданства и, если они находились за пределами России, высказывать намерение приехать в Россию в

12 Лента.ру (20202). Растет всеобщее недоверие, всеобщая боязнь, 22.05.2020. URL:

https://lenta.ru/articles/2020/05/22/migrant/

${ }^{13}$ См.: Известия (2020). В мэрии Москвы не увидели роста преступности среди мигрантов во время пандемии, 25.05.2020. URL: https://iz.ru/1015171/2020-05-25/v-merii-moskvy-ne-uvideli-rosta-prestupnosti-sredimigrantov-vo-vremia-pandemii; Егоров И. (2020). Кто сидит в Даркнете. Российская газета (Москва), Федеральный выпуск,108(8162). 20.05.2020

${ }^{14}$ К удивлению, статья, цитирующая слова заместителя Секретаря Совета безопасности РФ А.Н. Гребенкина «правоохранительным органам удалось не допустить роста преступности в миграционной сфере», вышла под заголовком «Рост преступности среди мигрантов зафиксировали в России». См.: Телеграф (2020). Pocm преступности среди мигрантов зафиксировали в России,. 21.05.2020. URL: https://rustelegraph.ru/news/202005-21/rost-prestupnosti-sredi-migrantov-zafiksirovali-v-rossii-90995

${ }^{15}$ См.: Несекретные материалы (2020). В Россию едет несколько миллионов мигрантов: первый рейс в коние июля, 29.06.2020. URL: https://nesekretno-net.ru/blog/43776301420/V-Rossiyu-edet-neskolko-millionovmigrantov-pervyiy-reys-v-konts?utm_referrer=mirtesen.ru

${ }^{16}$ Свой вклад в нагнетание истерии внес Д.А. Медведев, заявление которого в июне о риске роста преступности мигрантов было широко растиражировано массмедиа. См.: ТАСС (2020). Медведев предупредил о рисках роста преступности среди потерявших работу мигрантов, 09.06.2020. URL: https://tass.ru/obschestvo/8687177

17 Радио Азаттык (2020). Коронакризис в России: последствия для трудовых мигрантов, 17 .05. 2020. URL: https://rus.azattyk.org/a/30617025.html 
2020 г. После корректировки базы данных (отсева не отвечающих данным требованиям и тех, кто не прошел опрос полностью) выборка составила 2695 респондентов. Опрошено 1304 респондента, находящихся на территории России, и 1391 - за ее пределами. За немногими исключениями в формулировках вопросов, анкета была идентичной как для пребывающих в России, так и находящихся в посылающих странах.

Наряду с онлайн-опросом по аналогичной анкете и в это же время опрашивали по телефону (Computer Assisted Telephone Interviewing, CATI) граждан Киргизии, Таджикистана, Узбекистана и Украины, в подавляющем большинстве пребывающих в Москве и Московской области (300 респондентов). Для телефонного опроса использовали данные о респондентах, ранее принимавших участие в обследованиях Института социологии ФНИСЦ РАН. Как онлайн- опрос, так и САТІ-опрос проводили на русском языке.

Профили онлайн-респондентов, пребывающих в России и за ее пределами, практически идентичны. Среди опрошенных преобладают мужчины, более четверти респондентов имеют высшее образование, каждый десятый - неполное высшее. Средний возраст респондентов 37 лет (среди мужчин - 35 лет, женщин - 39 лет). Почти треть опрошенных назвались русскими, для большинства респондентов русский язык является материнским. Принявшие участие в CATI-опросе представляют иную социальную страту иностранцев - это мигранты с более низким уровнем квалификации и образования (с высшим и неполным высшим 17,1\%). Русских среди них существенно меньше, а русский язык назвали материнским лишь четверть респондентов (таблица 1).

Таблица 1. Основные социально-демографические характеристики мигрантов (онлайн-опрос и САТI), \% опрошенных

\begin{tabular}{|c|c|c|c|}
\hline \multicolumn{2}{|l|}{ Параметры } & $\begin{array}{c}\text { Онлайн-опрос (опрошенные } \\
\text { в России и за рубежом) }\end{array}$ & CATI \\
\hline Пол & Мужской & 62,4 & 68,9 \\
\hline \multirow[t]{6}{*}{ Возраст, лет } & До 20 & 4,6 & 0,3 \\
\hline & $20-29$ & 27,9 & 25,0 \\
\hline & $30-39$ & 28,4 & 35,1 \\
\hline & $40-49$ & 22,5 & 27,0 \\
\hline & $50-59$ & 11,4 & 12,5 \\
\hline & 60 и старше & 3,1 & 0,0 \\
\hline \multirow[t]{3}{*}{ Семейное положение } & Никогда не состоявшие в браке & 28,9 & 15,4 \\
\hline & $\begin{array}{l}\text { Состоящие в браке (включая } \\
\text { гражданский и религиозный) }\end{array}$ & 54,7 & 71,2 \\
\hline & Вдовые, разведенные & 16,4 & 13,4 \\
\hline Наивысшее & Начальное и незаконченное среднее & 6,3 & 3,6 \\
\hline законченное & Среднее общее & 25,8 & 48,5 \\
\hline \multirow[t]{4}{*}{ образование } & Начальное профессиональное & 9,1 & 8,0 \\
\hline & Среднее профессиональное & 22,4 & 22,1 \\
\hline & Неполное высшее & 10,3 & 4,0 \\
\hline & Высшее & 26,0 & 13,1 \\
\hline Национальность & Русские & 29,6 & 8,2 \\
\hline Родной язык & Русский & 61,3 & 25,7 \\
\hline
\end{tabular}

Онлайн-опросы чреваты смещениями в связи со спецификой интернет-аудитории, в которой преобладают молодые, образованные, городские респонденты. В нашем случае выборка также смещена в сторону более образованных мигрантов, что особенно наглядно при сравнении с САТІ-опросом, где представлен иной контингент. Другие явные смещения: 
повышенная доля русских и тех, для кого родным языком является русский. В то же время не фиксируется преобладание молодых контингентов иностранных граждан. Вероятно, занижена доля мигрантов с неурегулированным правовым статусом: об отсутствии действительных документов на пребывание/проживание и/или занятие трудовой деятельностью среди находящихся в России заявили всего 8,3\% иностранцев и еще $6,1 \%$ затруднились в ответе.

Опираясь на предшествующие массовые опросы, проводившиеся сотрудниками Института социологии ФНИСЦ РАН для нужд НИУ-ВШЭ (2011 г. - 8,5 тыс. респондентов; 2017 г. - 8,6 тыс. респондентов) и ведомственную статистику МВД России, можно констатировать недостаточную представленность среднеазиатских мигрантов и избыточную - молдавских и армянских (рисунок 2).

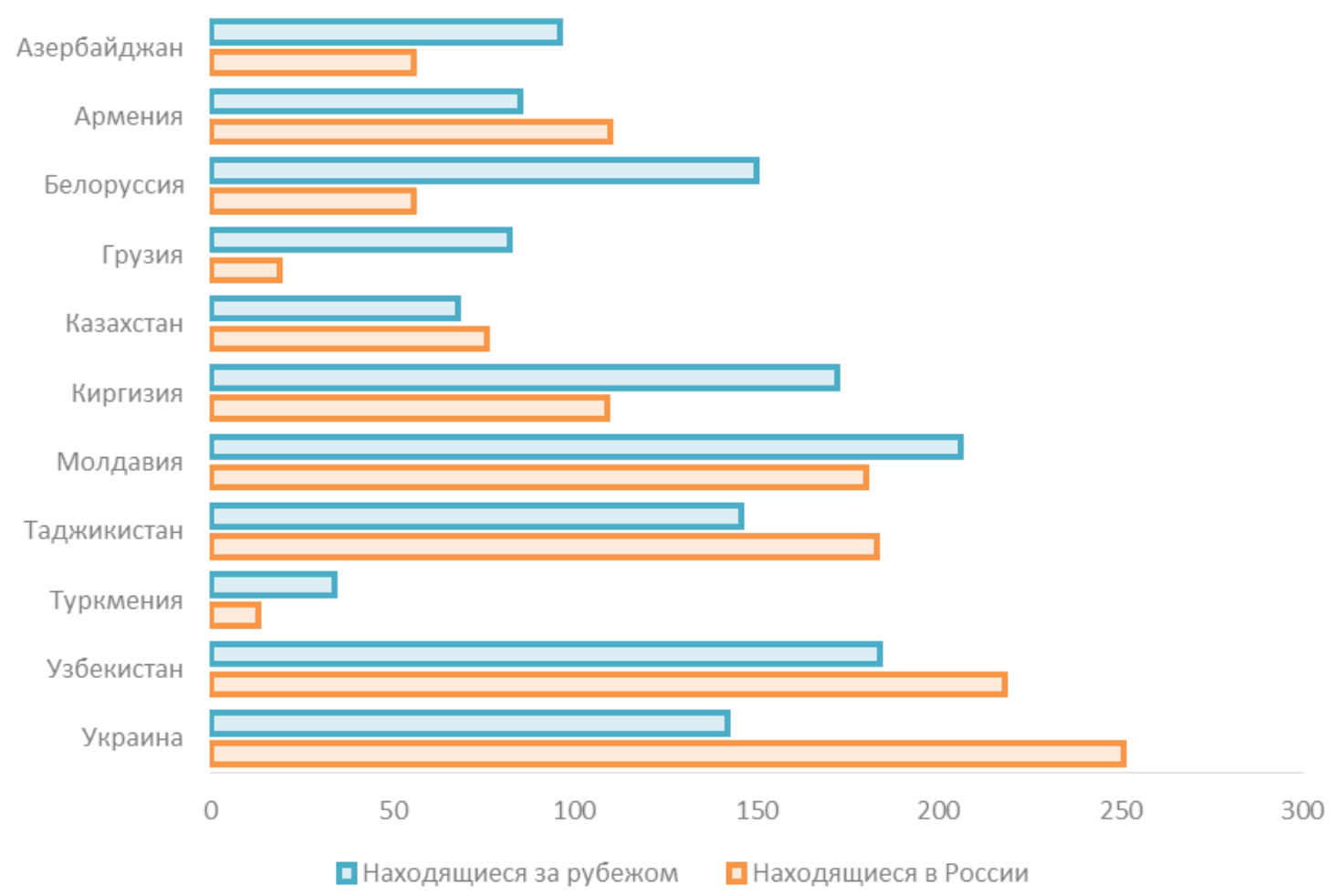

Рисунок 2. Распределение респондентов по странам гражданства, человек

Большинство мигрантов, находящихся в России, работают, либо ищут работу и готовы к ней приступить - таковых $71,1 \%$ респондентов ${ }^{18}$. Среди опрошенных за пределами России работать после приезда в Россию намерены практически столько же - 70,7\%. Основными видами экономической деятельности работавших на последнем рабочем месте в России (как находящихся на ее территории, так и за границей) являются строительство, гостиничный и ресторанный бизнесы, торговля, занятость в домашних хозяйствах. Иные сферы занятости участников CATI-опроса: треть заняты в торговле, значительная доля занятых в строительстве и ЖКХ (таблица 2).

\footnotetext{
18 Здесь и далее, если иное не оговорено, приводятся результаты онлайн-опроса. 
Таблица 2. Виды экономической деятельности мигрантов (онлайн-опрос и САТI), \% опрошенных

\begin{tabular}{|c|c|c|}
\hline Виды экономической деятельности & Онлайн-опрос & CATI \\
\hline Строительство & 26,8 & 17,1 \\
\hline Гостиницы и общественное питание & 14,1 & 3,9 \\
\hline $\begin{array}{l}\text { Оптовая и розничная торговля; ремонт автомобилей и } \\
\text { мотоциклов }\end{array}$ & 9,8 & 33,6 \\
\hline Помощь в домашних хозяйствах & 9,2 & 4,6 \\
\hline Транспорт, хранение & 7,5 & 8,6 \\
\hline Обрабатывающие производства & 6,4 & 3,6 \\
\hline ЖКХ, уборка зданий и территорий & 4,5 & 15,0 \\
\hline Здравоохранение, социальные услуги & 1,8 & 1,1 \\
\hline Прочие персональные услуги & 3,5 & 3,9 \\
\hline Другие, нет ответа & 16,4 & 8,6 \\
\hline Итого & 100,0 & 100,0 \\
\hline
\end{tabular}

Подавляющее большинство ответивших работают в одиночку и на микропредприятиях с численностью занятых до 15 человек (69,0\% по онлайн-опросу, 64,7\% по САТI) или на малых предприятиях с численностью от 16 до 100 человек (соответственно 19,4 и 24,8\%). Это предприятия, где наиболее распространена неформальная и незаконная занятость и которые больше всего пострадали от экономических последствий пандемии.

\section{МИГРАНТЫ В РОССИИ}

Трудовые мигранты и члены их семей, пребывающие на территории России, оказались в сложном положении. Российские власти предприняли ряд мер, препятствующих их социальной исключенности, - в первую очередь, пролонгируя документы, позволяющие мигрантам пребывать на территории России и заниматься трудовой деятельностью ${ }^{19}$. Предпринятые меры шли в русле типичных для других стран, заключающихся в упрощении легальных процедур и автоматическом пролонгировании необходимых мигрантам документов, облегчении их доступа к медицинским услугам ${ }^{20}$. Однако эти меры не пользовались безоговорочной поддержкой россиян ${ }^{21}$. В целом они не облегчили экономическое положение мигрантов: сокращение занятости в первую очередь в тех сферах, где работают мигранты, сделало иностранных граждан одной из наиболее уязвимых социальных групп.

Онлайн-опрос был проведен с целью получить ответы на следующие вопросы: В каких видах экономической активности сокращение занятости стало особенно

\footnotetext{
${ }^{19}$ Официальный интернет портал правовой информации. (2020). Указ Президента Российской Федерации от 18.04.2020 № 274 «О временных мерах по урегулированию правового положения иностранных граждан и лиц без гражданства в Российской Федерации в связи с угрозой дальнейшего распространения новой коронавирусной инфекции (COVID-19)». URL: http://publication.pravo.gov.ru/ Document/View/0001202004180001

${ }^{20}$ Обзор практик различных государств см.: (Малахов, Мотин 2020; OECD 2020; The World Bank 2020a).

${ }^{21}$ Согласно одному из онлайн-опросов, против них высказались 3/4 респондентов одной из деловых социальных сетей. См.: Опрос Telegram «БУДЬ В ТЕМЕ» (2020). Россияне против предложения Правительства выплачивать мигрантам МРОТ, 24 ТМ, 26.04.2020. https://24tm.ru/articles/40511-rossijaneprotiv-predlozhenija-pravitelstva-vyplachivat-migrantam-mrot-opros-telegram-bud-v-te.html
} 
болезненным для мигрантов? Каково их материальное положение? Насколько они готовы покинуть Россию в случае восстановления транспортных коммуникаций? Каковы их ближайшие и отдаленные планы, связанные с трудовой деятельностью и жизнью в России? В опросе приняли участие иностранные граждане, не имеющие второго (российского) гражданства, находящиеся на территории 78 регионов России, из них 52,4\% в Москве и Московской области и 10,9\% в Санкт-Петербурге и Ленинградской области.

Среди опрошенных много студентов (12,3\%), есть домохозяйки $(6,2 \%)$, неработающие пенсионеры (1,4\%). Еще 3,5\% - лица без определенного вида занятий, не отнесшие себя к какой-то категории и заметившие, что они не работают и не ищут работу. Социально-демографические профили иностранцев, которые не присутствуют на российском рынке труда, существенно отличаются от профилей тех, кто занят или ищет работу (таблица 3 ).

Таблица 3. Основные социально-демографические характеристики присутствующих на рынке труда и других категорий мигрантов в России, \% опрошенных

\begin{tabular}{|c|c|c|c|c|}
\hline \multicolumn{2}{|l|}{ Параметры } & $\begin{array}{c}\text { Работающие } \\
\text { и ищущие } \\
\text { работу }\end{array}$ & $\begin{array}{c}\text { Другие } \\
\text { категории } \\
\text { мигрантов }\end{array}$ & Итого \\
\hline Пол & Мужской & 64,9 & 50,0 & 61,2 \\
\hline \multirow[t]{6}{*}{ Возраст, лет } & До 20 & 1,2 & 15,6 & 4,7 \\
\hline & $20-29$ & 27,9 & 42,7 & 31,5 \\
\hline & $30-39$ & 31,2 & 14,2 & 27,1 \\
\hline & $40-49$ & 26,1 & 14,9 & 23,4 \\
\hline & $50-59$ & 11,9 & 9,8 & 11,4 \\
\hline & 60 и старше & 1,7 & 2,7 & 2,0 \\
\hline \multirow[t]{3}{*}{ Семейное положение } & Никогда не состоявшие в браке & 22,7 & 52,0 & 29,9 \\
\hline & $\begin{array}{l}\text { Состоящие в браке (включая } \\
\text { гражданский и религиозный) }\end{array}$ & 58,6 & 40,1 & 53,6 \\
\hline & Вдовые, разведенные & 18,7 & 7,9 & 16,5 \\
\hline \multirow{6}{*}{$\begin{array}{l}\text { Наивысшее } \\
\text { законченное } \\
\text { образование }\end{array}$} & $\begin{array}{l}\text { Начальное и незаконченное } \\
\text { среднее }\end{array}$ & 6,7 & 8,7 & 7,2 \\
\hline & Среднее общее & 31,2 & 16,7 & 27,7 \\
\hline & Начальное профессиональное & 8,5 & 7,3 & 8,2 \\
\hline & Среднее профессиональное & 22,2 & 23,0 & 22,4 \\
\hline & Неполное высшее & 8,5 & 23,3 & 12,2 \\
\hline & Высшее & 22,8 & 21,0 & 22,4 \\
\hline Национальность & Русские & 22,5 & 30,3 & 24,5 \\
\hline Родной язык & Русский & 52,6 & 55,3 & 53,3 \\
\hline
\end{tabular}

Среди неработающих мигрантов намного больше молодежи: свыше половины - до 30 лет, в основном это студенты. Если в возрастных группах до 40 лет преобладают мужчины, то старше 40 лет - женщины. По сути, не работающие мигранты - это конгломерат, с одной стороны, молодых учащихся юношей (средний возраст 22 года), с другой - 40-летних домохозяек и пенсионерок с небольшими вкраплениями пенсионеров.

Однако работающих и ищущих работу иностранных граждан большинство. Основными видами экономической деятельности респондентов, находящихся за пределами Московского мегаполиса, являются строительство, гостиницы и рестораны, торговля, помощь в домашнем хозяйстве, обрабатывающие производства. Несколько иная структура занятости в Московском мегаполисе, где меньше доля занятых в строительстве и торговле, 
но больше работающих в гостиничном и ресторанном бизнесе, помогающих в домашнем хозяйстве, в ЖКХ и оказывающих персональные услуги (таблица 4).

Таблица 4. Виды экономической деятельности мигрантов в Московском мегаполисе и других регионах России на последнем месте работы, \% ответивших

\begin{tabular}{|c|c|c|}
\hline Виды экономической деятельности & $\begin{array}{c}\text { Москва и } \\
\text { Московская область }\end{array}$ & $\begin{array}{l}\text { Другие регионь } \\
\text { России }\end{array}$ \\
\hline Строительство & 25,1 & 28,4 \\
\hline Гостиницы и общественное питание & 15,9 & 13,5 \\
\hline $\begin{array}{l}\text { Оптовая и розничная торговля; ремонт автомобилей и } \\
\text { мотоциклов }\end{array}$ & 9,8 & 13,2 \\
\hline Помощь в домашних хозяйствах & 12,7 & 5,8 \\
\hline Транспорт, хранение & 7,4 & 7,7 \\
\hline Обрабатывающие производства & 4,8 & 8,8 \\
\hline ЖКХ, уборка зданий и территорий & 6,4 & 2,5 \\
\hline Здравоохранение, социальные услуги & 1,2 & 3,3 \\
\hline Прочие персональные услуги & 4,2 & 2,5 \\
\hline Другие & 12,5 & 14,3 \\
\hline Итого & 100,0 & 100,0 \\
\hline
\end{tabular}

Труд опрошенных неплохо оплачивается: средняя заплата составляет 43,2 тыс. рублей (медианное значение 36 тыс. рублей). Лучше всего оплачиваются работающие в сфере профессиональной, научной и технической деятельности, в области информатики и связи, культуры и досуга (79,1 тыс. руб., медиана 62,4 тыс. руб.), в строительстве (49,4 тыс. руб.), хуже всего - занятые в ЖКХ (35,3 тыс. руб.), торговле (35,1 тыс. руб.). Заработки менее квалифицированных работников (САТІ-опрос) несколько меньше: средняя оплата их труда в строительстве - 42,8 тыс. рублей, в торговле - 32,6 тыс. рублей, в ЖКХ - 30,0 тыс. рублей.

Отметим предпринимательскую жилку опрошенных: $3,8 \%$ из них являются собственниками компании, $3,7 \%$ - зарегистрированными индивидуальными предпринимателями, еще 7,7\% - самозанятые.

Подавляющее большинство присутствующих на российском рынке труда работали в минувшем году $(88,8 \%)$. В этом году $8,7 \%$ из них не имели работы на всем протяжении с января по май. Максимальная занятость среди работавших в этом году в России пришлась на февраль, а пик безработицы - на апрель: если принять численность работавших в январе за 100 пп., то в феврале - 103,1, марте - 97,7, апреле - 66,2, мае - 71,2. Схожая картина сложилась по CATI-опросу с поправкой на то, что основным видом экономической деятельности респондентов, преимущественно выходцев из Средней Азии, является торговля: февраль - 103,6, март - 85,8, апрель - 53,5, май - 67,2.

Однако процессы с занятостью мигрантов, шедшие в регионах и в столичном мегаполисе, кардинально различаются. В Москве был установлен наиболее жесткий режим самоизоляции, достаточно жесткий режим был и в Московской области ${ }^{22}$, тогда как в других регионах - за немногими исключениями и, как правило, позже - карантин имел

\footnotetext{
${ }^{22}$ Следует учесть, что многие трудовые мигранты, работающие в Москве, проживают в Московской области и ограничение транспортного сообщения между Москвой и областью сократило их возможности работы в Москве.
} 
место в облегченном виде. Как следствие, уменьшение мигрантского рынка труда в мегаполисе было более значительным, чем в регионах (рисунок 3 ).

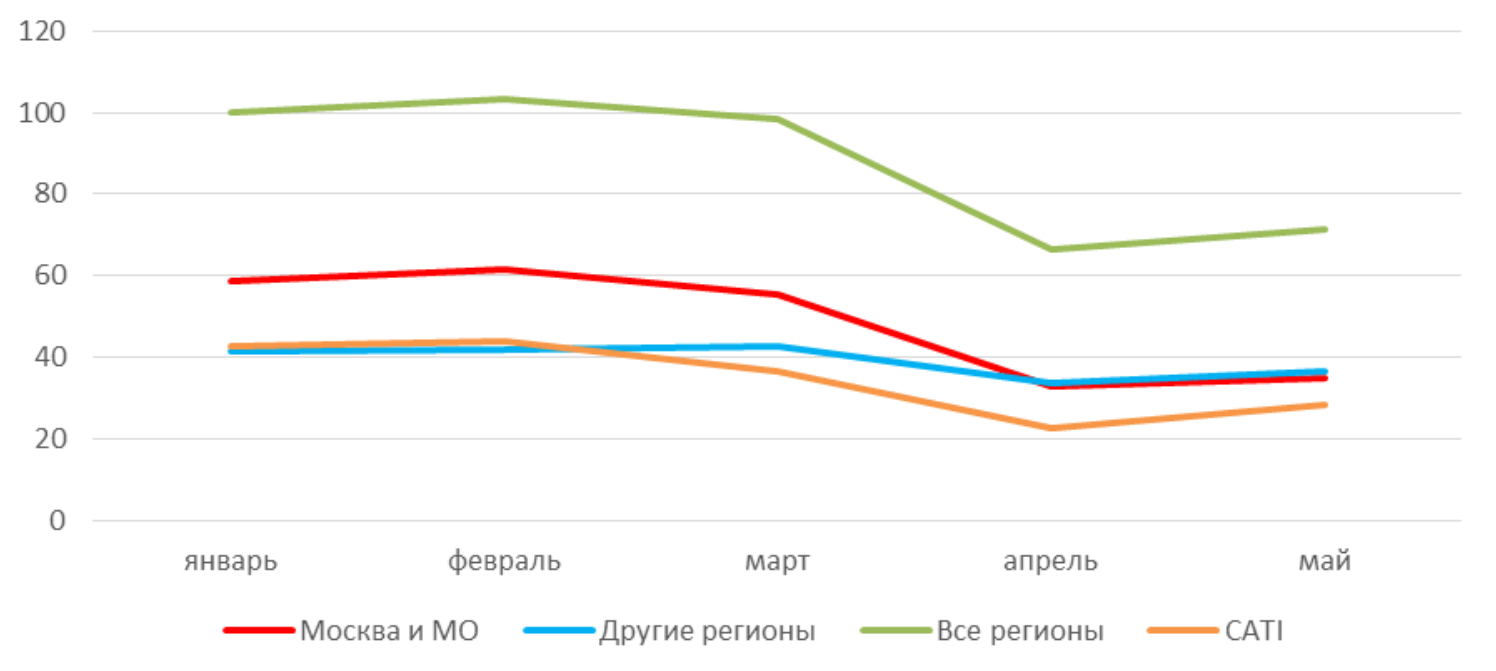

Рисунок 3. Динамика числа работающих в январе-мае 2020 г. в Московском мегаполисе и регионах России (все регионы январь 2020=100\%)

Занятость в мегаполисе начала сокращаться в марте, тогда как в регионах продолжался традиционный для этого времени года прирост занятости мигрантов. Если в мегаполисе в апреле число работающих респондентов сократилось по сравнению с мартом на 40,8\% (а по сравнению с февралем на 47,5\%), то в регионах - лишь на 21,2\%. Примечательно, что данные CATI-опроса демонстрируют такую же динамику занятости мигрантов, как и онлайн-опроса в мегаполисе. С одной стороны, это неудивительно: 95\% респондентов CATI пребывают в Московском регионе. С другой, - респонденты САТI заняты на худших рабочих местах, и это аргумент в пользу того, что кризис одинаково отразился на работниках разных занятий.

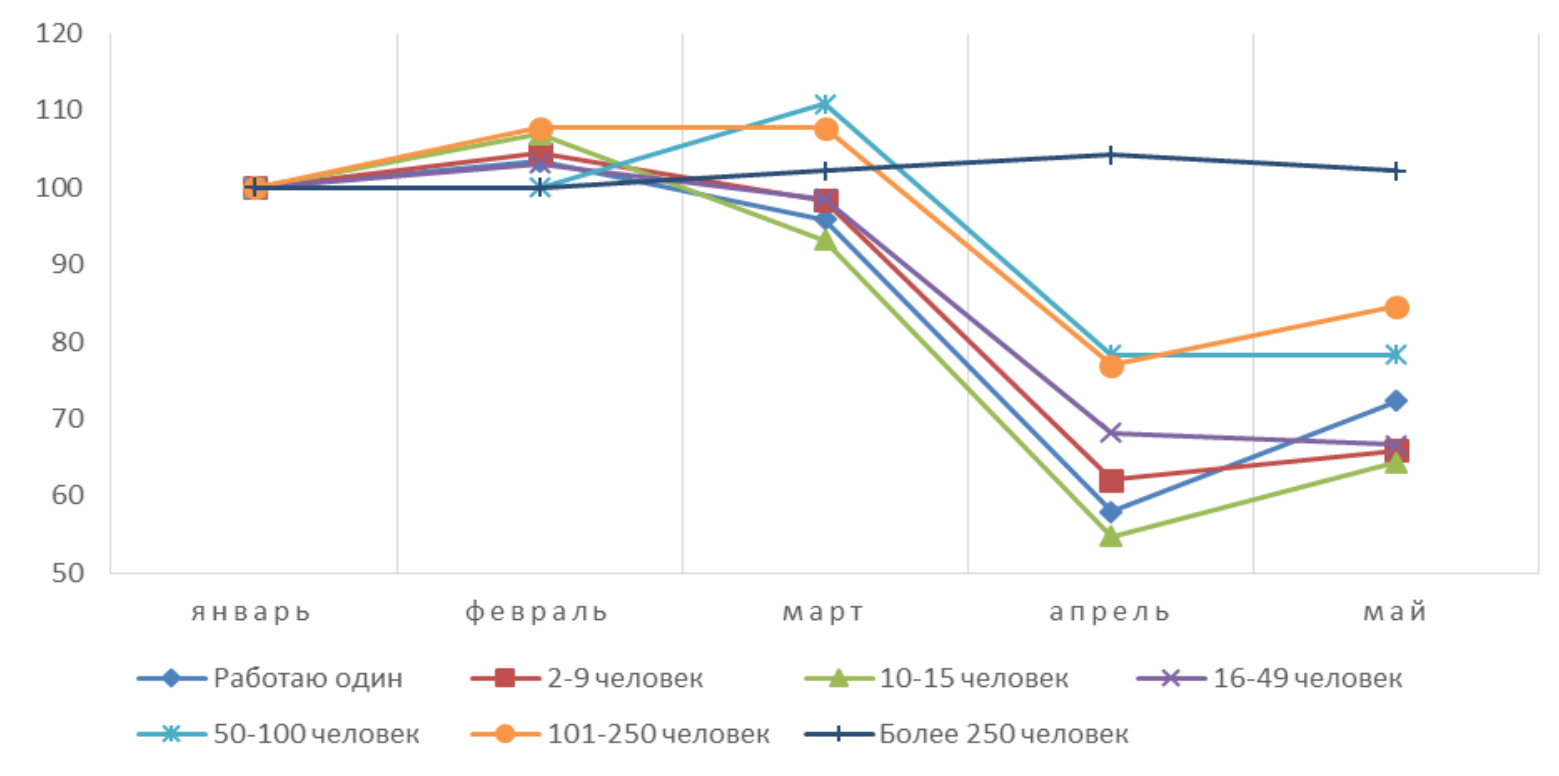

Рисунок 4. Изменение числа занятых в зависимости от количества работников предприятия (организации) в январе-мае 2000 г., \% (январь 2020 г. $=100 \%$ ) 
Весной 2020 г. наибольшую устойчивость продемонстрировали средние и крупные предприятия. Особенно сложно пришлось самозанятым и работающим на микропредприятиях, их численность сильно сократилась в апреле (рисунок 4).

Апрельское сокращение рынка труда миновало работников, составлявших костяк бизнеса. Работодатели, судя по всему, ориентировались на сохранение наиболее ценных сотрудников, избавляясь, в первую очередь, от менее опытных и квалифицированных. Более половины работавших в январе-мае 2020 г. (55,0\%) составляли те, кто не терял работу в это время. Это наиболее образованные (28,9\% с высшим образованием), лучше владеющие русским языком, среди них много русских (32,0\%). Сильнее пострадали хуже оплачиваемые самые социально уязвимые группы мигрантов: с неурегулированным правовым статусом - не имеющие никаких действительных документов на пребывание/проживание и/или занятие трудовой деятельностью в России (существенно реже теряли работу имевшие вид на жительство или разрешение на временное проживание); неформально занятые - чьи трудовые отношения основывались на устных соглашениях (или самозанятые, не оформившие отношения с государством). Если среди всех опрошенных доля неформально занятых составляла $38,7 \%$, а среди занятых в коллективах до 10 человек - более половины (51,8\%), то среди тех, кто постоянно работал на протяжении января-мая 2020 г., существенно меньше - 24,2\%. Вытесняемые с рынка труда наиболее уязвимые социальные группы мигрантов, с одной стороны, пополняют ряды безработных, с другой - формально улучшают статистику неформальной занятости.

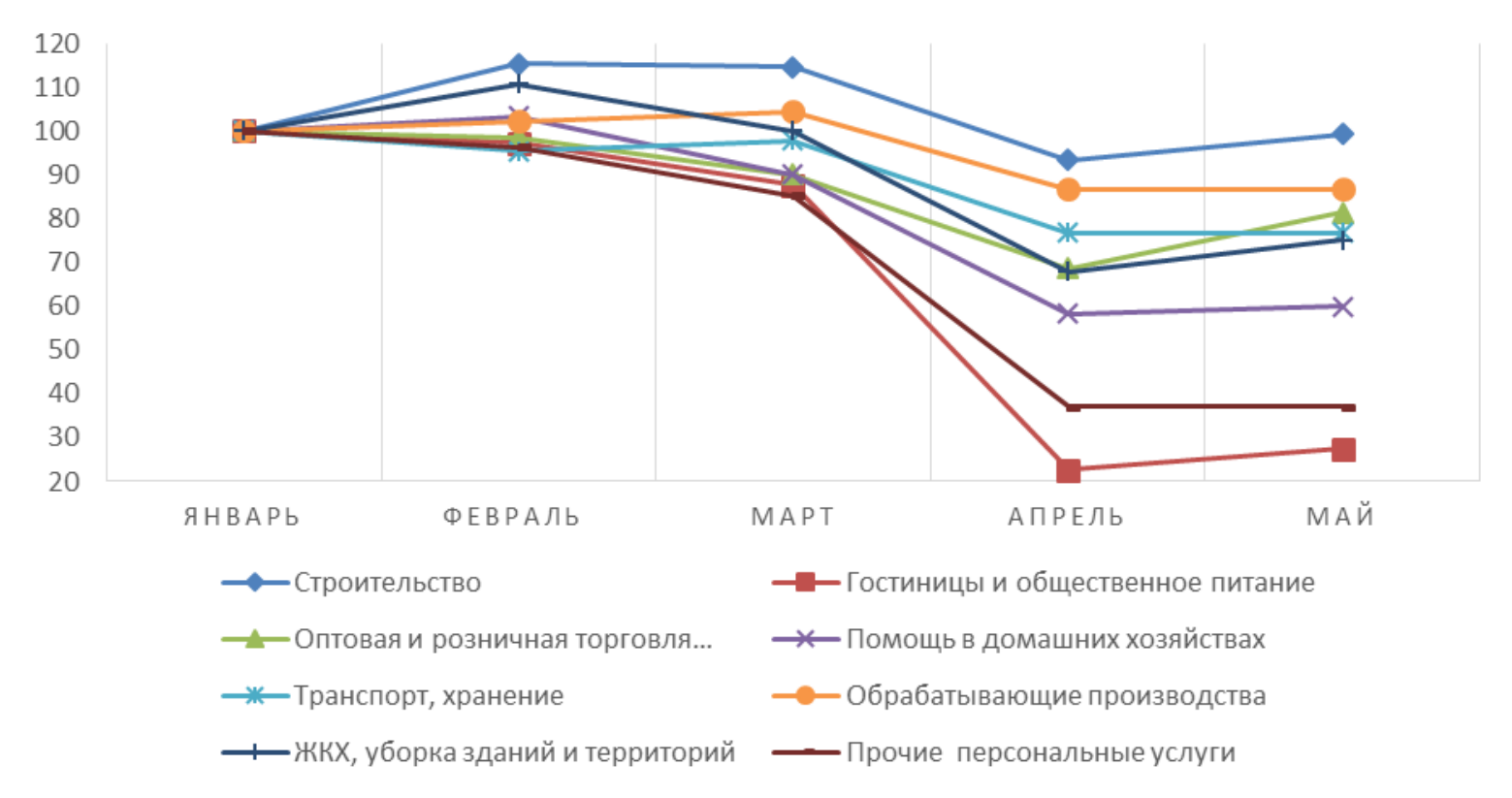

\section{Рисунок 5. Изменение численности занятых по основным видам экономической деятельности мигрантов в январе-мае 2000 г., \% (январь 2020 г. =100\%)}

Кризис, связанный с пандемией, ожидаемо сильней всего ударил по гостиничному и ресторанному бизнесу, где в самый тяжелый месяц (в апреле) работали только 23,3\% от работавших в феврале, персональным услугам (38,4\% работавших в феврале), помощи в домашнем хозяйстве $-56,4 \%$, торговле $-69,6 \%$, тогда как в строительстве $-81,0 \%$ (а в мае занятость в строительстве вышла на январский уровень; рисунок 5). 
Однако для менее квалифицированных работников (опрос САTI) ситуация была более драматична: в апреле, в самое трудное время, были заняты только $40 \%$ работавших на пике занятости в феврале в строительстве, торговле и на транспорте.

Меньше всего от сокращения занятости пострадали граждане Белоруссии, Казахстана, Армении и Украины. Сложнее всего пришлось гражданам Киргизии, Узбекистана и Таджикистана: в апреле среди граждан Киргизии работали 47,1\% занятых в феврале, среди граждан Узбекистана - 52,2\%, Таджикистана - 69,1\% (среди последних было меньше занятых в гостиничном и ресторанном бизнесе, наиболее пострадавшем в период локдауна). Аналогичная картина зафиксирована среди менее квалифицированных мигрантов: по CATI-опросу в апреле работали только 52,8\% работавших в феврале граждан стран Средней Азии.

Если среди российских работников после введения режима самоизоляции работу потеряли почти $10 \%$ из тех, у кого она была в докарантинный период (Гимпельсон, Капелюшников 2020) ${ }^{23}$, то среди мигрантов - около $40-45 \%{ }^{24}$ (в онлайн-опросе - каждый третий, в CATI-опросе - каждый второй).

Похоже, что в отличие от российских работников, в массовом порядке ощутивших сокращение оплаты труда, - реакция работодателей, характерная для экономических кризисов 2000-х, мигранты столкнулись с массовыми сокращениями, обусловленными закрытием бизнесов. Сокращение оплаты труда также имело место, особенно в наиболее пострадавших от кризиса гостиничном и ресторанном бизнесе, оптовой и розничной торговле, в которых работодатели сокращали, в первую очередь, лучше оплачиваемых более возрастных работников. Однако в ряде видов экономической активности (помощь в домашних хозяйствах, строительство) оплата труда даже несколько подросла (соответственно на 4,8 и 2,9\% в апреле по сравнению с февралем).

Наиболее значимыми причинами потери работы назывались объективные, обусловленные закрытием предприятия $(31,5 \% \text { опрошенных })^{25}$, сокращением числа работников (8,5\%). Крайне редко работники проявляли инициативу и уходили сами, даже если им не платили $(15,1 \%)$. Весьма распространена была ситуация, когда организация не работала из-за режима изоляции, работнику не платили, но помогали, чем могли (продуктами питания, например), он числился как работающий и ждал начала работы $(18,9 \%)$. Значительная часть респондентов $(26,0 \%)$ не детализировала причину потери работы, расплывчато указывая на пандемию. 58,1\% ответивших знают родственников, друзей, знакомых, потерявших работу в России в этом году и вернувшихся на родину, однако еще больше (62,8\%) отмечали, что лишившиеся работы остались в России.

\footnotetext{
${ }^{23}$ По другим оценкам - каждый четвертый. См.: Пипия К. (2020). От изоляции - к миграции. Ведомости, 03.06.2020. URL: https://www.vedomosti.ru/opinion/articles/2020/06/03/831861-izolyatsii-migratsii

${ }^{24}$ В массмедиа появлялись и более высокие оценки числа мигрантов, потерявших работу, ссылавшиеся на неведомые опросы. См.: Хиромон Б. (2020). ІОМ: около 60 процентов мигрантов в России потеряли доходы Радио Озоди, 03.06.2020. URL: https://rus.ozodi.org/a/30650669.html

${ }^{25}$ Особенно часто сталкивались с закрытием предприятия в Московском мегаполисе (37,2\%), тогда как в других регионах $-21,9 \%$ респондентов.
} 
В наиболее сложном положении оказались ищущие работу: у 57,3\% из них денег не хватает на самое необходимое. Не столь катастрофическое положение работающих, домохозяек, учащихся, пенсионеров, среди которых таких крайне нуждающихся 27,9\%. Хуже всего ситуация в Москве, где денег не хватает на самое необходимое у 44,8\% иностранных граждан. По телефонному опросу, каждый седьмой мигрант в Москве жаловался, что денег нет даже на еду, каждый третий - нет денег на покупку одежды.

Боязнь остаться без средств к существованию преобладает над боязнью коронавируса: первых втрое больше, чем вторых. Корона-диссидентство вкупе с бравадой также имеет место быть: 16,7\% не боятся ни того, ни другого. Еще больше таковых зафиксировано в CATI-опросе - 23,4\%, что наводит на мысль о большей распространенности ковид-диссидентства среди менее образованных мигрантов.

В 2020 г. планирует работать подавляющее большинство респондентов, включая учащихся, домохозяек, пенсионеров, ранее не присутствовавших на рынке труда: 78,7\% точно планируют работать, еще $7,8 \%$ рассматривают такую возможность. Однозначно отвергают свою работу в этом году в России лишь 6,5\% респондентов и 7,0\% затруднились с ответом. Среди тех, кто планирует продолжать работу или начать работать в России в этом году, 42,7\% уверены, что им удастся сохранить работу, 42,8\% - что смогут найти работу (хотя часть из них сомневаются, что это удастся сделать быстро). Не уверены, что вообще найдут работу, 5,9\%, затруднились с ответом $8,7 \%$.

Оценки экспертами возможного оттока мигрантов из России после возобновления межгосударственного транспортного сообщения разнятся. Некоторые из них предполагают значительный выезд из России. Назывались и возможные масштабы оттока - до трети (Абашин 2020) или даже свыше половины иностранных граждан (Рязанцев 2020). Но этот отток спустя месяцы обернется существенным возвратным движением. Сторонники масштабного сокращения числа трудовых мигрантов чаще всего указывают на прецеденты предшествующих экономических кризисов, возрастающую конкуренцию иностранцев на рынке труда с российскими работниками, лишившимися работы. Более умеренные оценки базируются на кардинальных отличиях нынешнего экономического кризиса от предыдущих, на оценке экономической ситуации в основных посылающих странах, факторах, выталкивающих потенциальных мигрантов на российский рынок труда.

Однако 78,2\% работающих и 75,4\% ищущих работу респондентов и не думали выезжать из Россию в ближайшие месяцы (по крайней мере, до сентября-октября), лишь каждый десятый из них рассматривал возможность временно вернуться на родину, переждать там трудности и опять возвратиться в Россию (таблица 5). В телефонном опросе зафиксированы схожие цифры: оставаться в России пока намерены 78,9\%, переждать проблемы на родине - 10,0\%. Иностранные работники не стремятся покидать рынок труда, полагаясь на свои возможности трудоустройства ${ }^{26}$. Возможность возвращения на родину,

\footnotetext{
${ }^{26}$ Схожие данные были получены по намерениям украинских трудовых мигрантов в Польше, 85\% которых не собирались выезжать на родину. См.: Укринформ (85\% работников в период пандемии хотят остаться в Польше, 05.05.2020. URL: https://www.ukrinform.ru/rubric-society/3019588-85-rabotnikov-v-period-pandemiihotat-ostatsa-v-polse.html)
} 
чаще временного, больше рассматривают учащиеся, лица без определенных занятий, пенсионеры, домохозяйки (таблица 5).

Таблица 5. Ближайшие планы респондентов на пребывание в/отъезд из России, \% опрошенных

\begin{tabular}{|c|c|c|c|c|}
\hline \multirow[b]{2}{*}{$\begin{array}{l}\text { «Какие у Вас ближайшие } \\
\text { планы (до сентября-октября } \\
2020 \text { г.)»?» }\end{array}$} & \multicolumn{2}{|c|}{ Онлайн-опрос } & \multicolumn{2}{|c|}{ CATI-опрос } \\
\hline & $\begin{array}{c}\text { работающие и } \\
\text { ищущие работу }\end{array}$ & $\begin{array}{c}\text { не работающие } \\
\text { и не ищущие } \\
\text { работу }\end{array}$ & $\begin{array}{c}\text { работающие и } \\
\text { ищущие работу }\end{array}$ & $\begin{array}{c}\text { не работающие } \\
\text { и не ищущие } \\
\text { работу }\end{array}$ \\
\hline Оставаться в России & 77,3 & 62,5 & 80,9 & 67,4 \\
\hline $\begin{array}{l}\text { Вернуться на родину, там } \\
\text { переждать трудности и } \\
\text { потом приехать в Россию }\end{array}$ & 9,2 & 16,0 & 7,8 & 23,3 \\
\hline $\begin{array}{l}\text { Вернуться на родину } \\
\text { насовсем }\end{array}$ & 3,6 & 5,1 & 5,9 & 4,7 \\
\hline Не знаю & 9,9 & 16,5 & 5,5 & 4,7 \\
\hline Итого & 100,0 & 100,0 & 100,0 & 100,0 \\
\hline
\end{tabular}

Особо важно, как оценивают ситуацию выходцы из среднеазиатских государств основных стран происхождения мигрантов. Но настроения мигрантов из Киргизии, Таджикистана и Узбекистана аналогичны настроениям мигрантам из других стран: оставаться в России, несмотря ни на что (таблица 6). Скорее всего, их краткосрочные планы обусловлены не столько складывающейся ситуацией в России, сколько обстановкой на родине и оценкой всех плюсов и минусов краткосрочного и недешевого отъезда.

\section{Таблица 6. Ближайшие планы на пребывание в/отъезд из России граждан Киргизии, Таджикистана и Узбекистана, \% опрошенных}

\begin{tabular}{|c|c|c|}
\hline $\begin{array}{l}\text { «Какие у Вас ближайшие планы (до сентября-октября } \\
2020 \text { г.)»?» }\end{array}$ & Онлайн-опрос & CATI \\
\hline Оставаться в России & 70,9 & 78,8 \\
\hline $\begin{array}{l}\text { Вернуться в свою страну, там переждать трудности и } \\
\text { потом приехать в Россию }\end{array}$ & 11,2 & 9,2 \\
\hline Вернуться в свою страну насовсем & 4,7 & 6,5 \\
\hline Нет ответа, з/о & 13,1 & 5,4 \\
\hline Итого & 100,0 & 100,0 \\
\hline
\end{tabular}

Учитывая, что значительная часть респондентов не определилась со своими ближайшими планами, можно полагать, что покинуть Россию в ближайшие месяцы (при условии восстановления транспортного сообщения и относительно стабильной ситуации с коронавирусом в России и странах происхождения) могут, с учетом складывающейся экономической конъюнктуры, около 20\% мигрантов, две трети из которых вернутся на российский рынок труда в этом же году.

Более половины тех немногих, кто собирается уехать из России, готовы выехать сразу после восстановления транспортного сообщения. Но 21,5\% опрошенных увязывают готовность с отъездом с ситуацией с коронавирусом в России и на родине, каждый пятый с наличием денег на билет, а каждый седьмой - с другими обстоятельствам, связанными с семьей, работой и др.

Принявшие участие в опросе в большинстве своем интегрированы в российское общество. Они дорожат работой в России и опасаются ее потерять. Значительная часть мигрантов имеют вид на жительство или разрешение на временное проживание $(24,8 \%$ 
среди респондентов онлайн-опроса и $30,1 \%$ по опросу CATI) - документы, позволяющие более свободно чувствовать себя в повседневной жизни в России и особенно на рынке труда. У подавляющего большинства из них есть приемлемое жилье, чаще всего - съемная отдельная квартира, причем $11,8 \%$ респондентов или членов его/ее семьи являлись собственниками жилья, у 6,9\% опрошенных жилье было собственностью жены (мужа), партнера. Почти у половины из тех, кто проживает в России с супругом или партнером, она(он) имеют российское гражданство. Неудивительно, что, отвечая на вопрос о долгосрочных миграционных планах, подавляющее большинство намерено либо остаться в России навсегда, либо осуществлять циркулярные миграции между Россией и страной происхождения.

\section{МИГРАНТЫ НА РОДИНЕ}

За последние два десятилетия иностранные работники стали неотъемлемой частью российского рынка труда. Согласно результатам федерального статистического наблюдения за использованием труда мигрантов, в 2019 г. иностранцев нанимали 168 тыс. российских предпринимателей и почти 1,4 млн российских домохозяйств (Росстат 2020а). В свою очередь, массовая трудовая миграция из бывших союзных республик в Россию смягчает проблемы безработицы в этих странах. Всего, по нашим оценкам, основанным на данных ГУВД МВД РФ и на статистике Международной организации труда, на работу в Россию до коронакризиса выезжало более $16 \%$ от численности рабочей силы Армении и Киргизии, около 13\% - Узбекистана, и более 45\% - Таджикистана. Для миллионов домохозяйств работа в России стала важным источником доходов. Так, например, в 2019 г. объемы денежных переводов мигрантов составляли почти $30 \%$ от валового внутреннего продукта Киргизии и Таджикистана, 3/4 всех переводов в эти страны поступили из России (The World Bank 2020b).

Введение режима самоизоляции в России и приостановка международных транспортных сообщений стали сильнейшим шоком не только для тех, кто находился в России, но и для тех, кто собирался приехать в нее в марте-июне 2020 г. Именно те, кто вернулся домой из России в 2020 г., а также те потенциальные мигранты, которые не смогли въехать в Россию после разрыва международных транспортных связей, находились во втором фокусе нашего исследования. Каково их экономическое положение на родине? Как скоро они готовы вернуться в Россию в случае открытия границ? Каковы их долгосрочные миграционные планы? На эти вопросы должны были дать ответы 1391 иностранных граждан, находившихся в момент опроса за пределами России. Среди респондентов 15\% составляли граждане Молдавии, 13,2\% - Узбекистана, 12,4\% Киргизии, 10,9\% - Белоруссии, 10,5\% -Таджикистана, 10,3\% - Украины, 6,9\% Азербайджана, 6,1\% - Армении, 4,9\% - Казахстана, 2,4\% - Туркмении, 1,4\% - других государств.

Еще раз подчеркнем, что выборка оказалась сильно смещенной в сторону русских и лиц с высшим образованием. Так, среди респондентов доля тех, кто отнес себя по национальности к русским, составила $34,7 \%$. Второй по численности национальной группой были таджики $(9,2 \%)$, третьей - узбеки $(8,9 \%)$. Заметим, что в общем числе 
трудовых мигрантов по данным миграционного учета явно преобладают граждане Узбекистана и Таджикистана (в 2019 г. - почти 60\%). Почти четверть опрошенных являются билингвами, т. е. родным они назвали не только русский, но и другой язык. Высшее образование в нашем случае имели $28,7 \%$ респондентов, неполное высшее и среднее профессиональное - 31,9\%. Это, примерно, соответствует уровню образования населения России в возрасте от 15 до 59 лет - в 2010 г. 25,8\% россиян имели высшее образование и $39 \%$ - неполное высшее или с среднее специальное. Но уровень образования респондентов был более высоким, чем у их соотечественников на родине. Так, в Киргизии высшее образование имеют примерно $15 \%$ взрослого населения, в Таджикистане - порядка $10 \%$.

Метод опроса заставлял предположить, что выборка даст смещение в пользу молодых возрастов, однако этого не произошло. В возрасте от 50 лет и старше находилось почти 20\% респондентов, 30\% респондентов были моложе 30 лет, другая половина находилась в средних трудоспособных возрастах от 30 до 50 лет. Около 2/3 респондентов мужчины, что в целом соответствует половой структуре потока трудовых мигрантов в Россию.

Большая часть респондентов (свыше 70\%) ранее посещали Россию. Из общего числа респондентов 20,5\% недавно приехали из России и не могут вернуться в нее из-за коронавирусных ограничений, 35,8\% ездят в Россию время от времени, еще 28,4\% собираются в Россию впервые. Остальные так или иначе связаны с Россией (родственники, командировки, бизнес, туризм и др.). Среди респондентов особый интерес вызывают те, кто приезжал на срок от трех месяцев и более, т. е. работать или учиться ${ }^{27}$. Таких трудовых и учебных мигрантов в выборке оказалось 63\%. Более $28 \%$ респондентов последний раз въезжали в Россию в 2019 г., около 10\% - в 2018 г., 8\% - в 2020 г., остальные 54\% - до 2018 г. Но более половины опрошенных (55\%) уехали из России в 2019 (27,5\%) и 2020 $(27,5 \%)$ годах.

Как уже отмечалось выше, эпидемия коронавируса и режим изоляции нарушили нормальный ход миграционных процессов со свойственной им сезонной компонентной. В январе въезд в Россию традиционно находится на минимальном уровне; большинство трудовых мигрантов приезжают в страну в марте-мае, а возвращаются на родину поздней осенью и в начале зимы до января-февраля следующего года. По данным опроса, в 2019 г. число вернувшихся на родину в марте было примерно таким же, как и в январе, феврале или в апреле, и почти в 6 раз меньше, чем в декабре. В 2020 г. респондентов, уехавших из России в марте, было в 2,5 раза больше числа уехавших в январе.

\footnotetext{
${ }^{27}$ Напомним, что 3 месяца или 90 суток - значимый интервал в Российском миграционном законодательстве. Согласно его положениям, срок временного пребывания в Российской Федерации иностранного гражданина, прибывшего в порядке, не требующем получения визы, не может превышать девяносто суток суммарно в течение каждого периода в сто восемьдесят суток. По истечение этого срока требуется получение разрешительных документов на пребывание, в том числе о привлечении к трудовой деятельности (патент или ходатайство от работодателя), либо ходатайство образовательной организации, в которой иностранный гражданин обучается. См. Федеральный закон от 25.07.2002 №115-Ф3 (ред. от 24.04.2020) "О правовом положении иностранных граждан в Российской Федерации" (с изм. и доп., вступ. в силу с 07.07.2020). Статья 5. Временное пребывание иностранных граждан в Российской Федерации.
} 
Потеря работы и коронавирусная эпидемия послужили главными выталкивающими факторами из России. Среди тех, кто вернулся на родину в 2020 г., преобладали строители (более $30 \%$ ), работники гостиниц и общественного питания (11\%), торговли и транспорта (по 8,2\%). Но возвратившиеся мигранты на родине фактически столкнулись с теми же трудностями, что и в России: из-за принятых коронавирусных мер возможности трудоустройства заметно уменьшились. Среди тех, кто вернулся домой в 2020 г., в начале июня работали только 40\%, более $50 \%$ не работали, чуть менее $10 \%$ учились. Среди всех респондентов занятые составили $51,6 \%$, ищут работу $24,5 \%$, не работают и не ищут работу примерно 6\%, учатся 6,7\%, домохозяйки - 6\%, пенсионеры - примерно 5\%.

Возвращение на родину в условиях коронавирусной эпидемии и мер борьбы с нею, ограничение международных поездок со стороны всех государств негативно повлияли на благосостояние семей трудовых мигрантов в странах их происхождения. Средний ежемесячный заработок трудовых мигрантов в России в начале 2020 г. составлял 47 тыс. рублей. Примерно таким же он был и в 2019 г. Согласно данным Росстата, это в целом соответствует среднему заработку по России в феврале 2020 г. (Росстат 2020b: 232). Если опираться на результаты предшествующих массовых опросов, проведенных сотрудниками Института социологии ФНИСЦ РАН для нужд НИУ-ВШЭ (2011 г. - 8,5 тыс. респондентов; 2017 г. - 8,6 тыс. респондентов), то можно предположить, что, в среднем, более $40 \%$ своего ежемесячного дохода они переводили на родину. Прекращение денежных поступлений из России осложнило и без того непростое экономическое положение семей трудовых мигрантов. Только $20 \%$ респондентов заявили, что они ни в чем не нуждаются, еще 17,5\% надеются продержаться без посторонней финансовой и материальной помощи ближайшие два месяца. Остальные в той или иной степени вынуждены экономить или прибегать к внешней поддержке. Это касается как тех, кто никогда не работал в России, так и тех, кто только недавно, в 2019 или в 2020 г., вернулся из нее. Особо сложное положение у тех респондентов, кто в момент опроса не работал. С материальными трудностями сталкиваются 75\% семей неработающих и половина семей работающих респондентов.

Для большей части опрошенных перспективы улучшения материального положения так или иначе связаны с работой в России. Среди респондентов, которые работали или учились в России, 54\% собираются приехать в Россию на срок от трех месяцев и более, $11,4 \%$ - на срок менее трех месяцев, остальные на момент опроса не приняли решения. Среди респондентов, собравшихся в Россию впервые, доля намеревающихся выехать на срок три месяца и более, равна $35 \%$, на срок менее трех месяцев - 23\%, остальные респонденты не определились с ответом. Из числа опрошенных, которые вернулись из России в 2019 и 2020 г., 57\% планируют вернуться в нее на срок от трех месяцев и более.

Почти у половины потенциальных мигрантов чемоданные настроения. Около $60 \%$ из числа тех, кто собирается приехать на 3 месяца и более, и 55\% из тех, кто собирается приехать на короткий срок (менее трех месяцев), ответили, что приедут в Россию, как только восстановится транспортное сообщение или будут собраны деньги на билет. Ситуация с коронавирусом является определяющей для выезда для 22\% респондентов, намеревающихся пробыть в России более трех месяцев, и для 27\% - менее трех месяцев. По словам остальных респондентов, момент отъезда для них определяется другими, прежде 
всего, семейными обстоятельствами. Обратим внимание на то, что среди мигрантов, вернувшихся из России в 2019 и 2020 г., почти 75\% готовы вернуться в нее сразу после восстановления транспортного сообщения.

В момент опроса респонденты были настроены оптимистично по отношению к получению работы в России. В общей сложности 67\% респондентов уверены, что быстро ее найдут. Среди тех, кто собирается уехать сразу после восстановления транспортного сообщения, таковых 80\%. Меньше оптимизма у тех, кто впервые приезжает в Россию: чуть больше половины (54\%) из них уверены, что работу в России можно найти быстро. Но в целом почти 90\% потенциальных мигрантов уверены, что работу в России они рано или поздно найдут.

Таким образом, в странах СНГ в условиях антикоронавирусных мер накапливается высокий потенциал для миграции в Россию. Этому способствует коронакризис в самих странах происхождения мигрантов, сопровождающийся сжатием рынка труда и падением доходов значительной части населения. Как показал опрос, потенциальных мигрантов в лице респондентов не пугает («не боятся») коронавирусная ситуация в России: каждый четвертый (25\%) пренебрежительно относится к вероятности заболеть коронавирусом. Большую (40\%) часть респондентов пугает перспектива остаться без средств к существованию. Особенно сильны миграционные намерения у имевших опыт работы или учебы в Российской Федерации, включая тех, кто был в России в 2019 и 2020 годах, подкрепляемые уверенностью в том, что в России можно быстро найти работу.

\section{ЗАКЛЮЧЕНИЕ}

В отличие от предшествующих экономических кризисов, когда численность трудовых мигрантов изменялась в соответствии с экономической конъюнктурой в России, в период коронавирусной пандемии сложилась кардинально иная ситуация, когда более значимыми стали факторы, выталкивающие потенциальных мигрантов из стран происхождения на российский рынок труда. Находящиеся в России трудовые мигранты не выказывают стремления ее покидать, а у тех, у кого были намерения переждать трудности на родине до осени, с каждым днем из-за отсутствия транспортного сообщения снижается стимул к выезду из России. Напротив, «навес» численности потенциальных трудовых мигрантов в посылающих странах постоянно возрастает. О его масштабах можно судить по данным ГУВМ МВД РФ согласно которым в апреле-июне 2020 года в России на миграционный учет с целью «работа» было поставлено на почти на 1,3 млн иностранных граждан меньше, чем в 2019 г. По данным Пограничной службы ФСБ России за эти же три месяца текущего года с целью въезда «работа» российскую границу пересекли всего 1,9 тыс.(!) иностранцев против 1,2 млн за тот же период в прошлом году. В июле-сентябре ограничения (при некоторых послаблениях) на международное транспортное сообщение со странами основными поставщиками трудовых мигрантов в целом сохранились. Если предположить, что состояние рынка труда в 2020 г. при отсутствии пандемии не должно было существенно отличаться от предыдущего года, за период с апреля по сентябрь из-за коронавирусных ограничений в Россию не въехало более 2,2 млн трудовых мигрантов. С учетом сохранения транспортных ограничений до конца года эта оценка увеличится и превысит как минимум, 
3 млн человек.

Миграция имеет огромное значение для посылающих стран. Во-первых, трудовая миграция смягчает давление на рынке труда в странах с быстро растущим молодым населением (Киргизия, Узбекистан, Таджикистан) или странах со «сжимающимся» рынком труда (Армения, Молдавия, Украина). Так, в 2019 г. в трудовой миграции участвовало 47\% рабочей силы Таджикистана, не менее 17,5\% - Киргизии, не менее $16 \%$ - Армении, 14\% Узбекистана. Хотя частично идет переориентация потоков трудовых мигрантов из Украины и Молдавии в Европу, Россия по-прежнему остается в числе главных направлений миграции и из этих стран. Во-вторых, страны происхождения мигрантов несут существенные потери от снижения притока денежных переводов трудовых мигрантов это относится, прежде всего, к тем странам, в которых денежные переводы из России составляют значительную величину по отношению к ВВП (Армения, Киргизия, Таджикистан). По нашим оценкам, основанным на данных Банка России и статистике Всемирного банка, при условии сохранения ограничений на въезд в Российскую Федерацию объемы переводов мигрантов в 2020 г. по сравнению с 2019 г. могут уменьшиться в странах СНГ на $30 \%$, что сильно ударит по благосостоянию населения этих стран, стабильности их финансовых систем и снизит размеры инвестиций в их экономику.

В условиях экономического спада и сокращения спроса на труд уменьшение предложения иностранной рабочей силы выглядит в России, как и в других странах, естественным и ожидаемым. Однако в регионах и отраслях с высокой концентрацией мигрантов, в отраслях с сильной сезонной составляющей (сельское хозяйство, индивидуальное строительство) недостаток дешевой рабочей силы может осложнить процесс их восстановления.

Из-за коронакризиса в России наметился дефицит рабочих рук низкой и средней квалификации в строительстве, торговле, транспорте и складском хозяйстве, а также средней и высокой квалификации - в сферах помощи в домашних хозяйствах, персональных услугах (видах экономической деятельности, в которых доля расходов на труд максимальна и где труд мигрантов особенно заметен).

Отчасти это наблюдалось уже на дне кризиса: на транспорте и в складских хозяйствах, в домашних хозяйствах и строительстве оплата труда опрошенных мигрантов возросла соответственно на 10, 4,8 и 2,9\% в апреле по сравнению с пиковым февралем. Об этом сигнализирует и Росстат: средняя зарплата россиян в транспортировке и хранении возросла в феврале - апреле на $10,3 \%$, в строительстве - на $0,8 \%$. Это означает, что, с одной стороны, часть «мигрантских» рабочих мест может быть занята россиянами - как местными, так и внутрироссийскими мигрантами. С другой - неизбежен рост стоимости товаров и услуг в тех видах экономической активности, где мигранты занимают или занимали значимые позиции.

Исследование показало, что потенциал трудовой миграции из стран СНГ остается достаточно высоким. При этом достаточно высоким и нереализованным является и потенциал для переселения и интеграции в России (рисунок 6). 


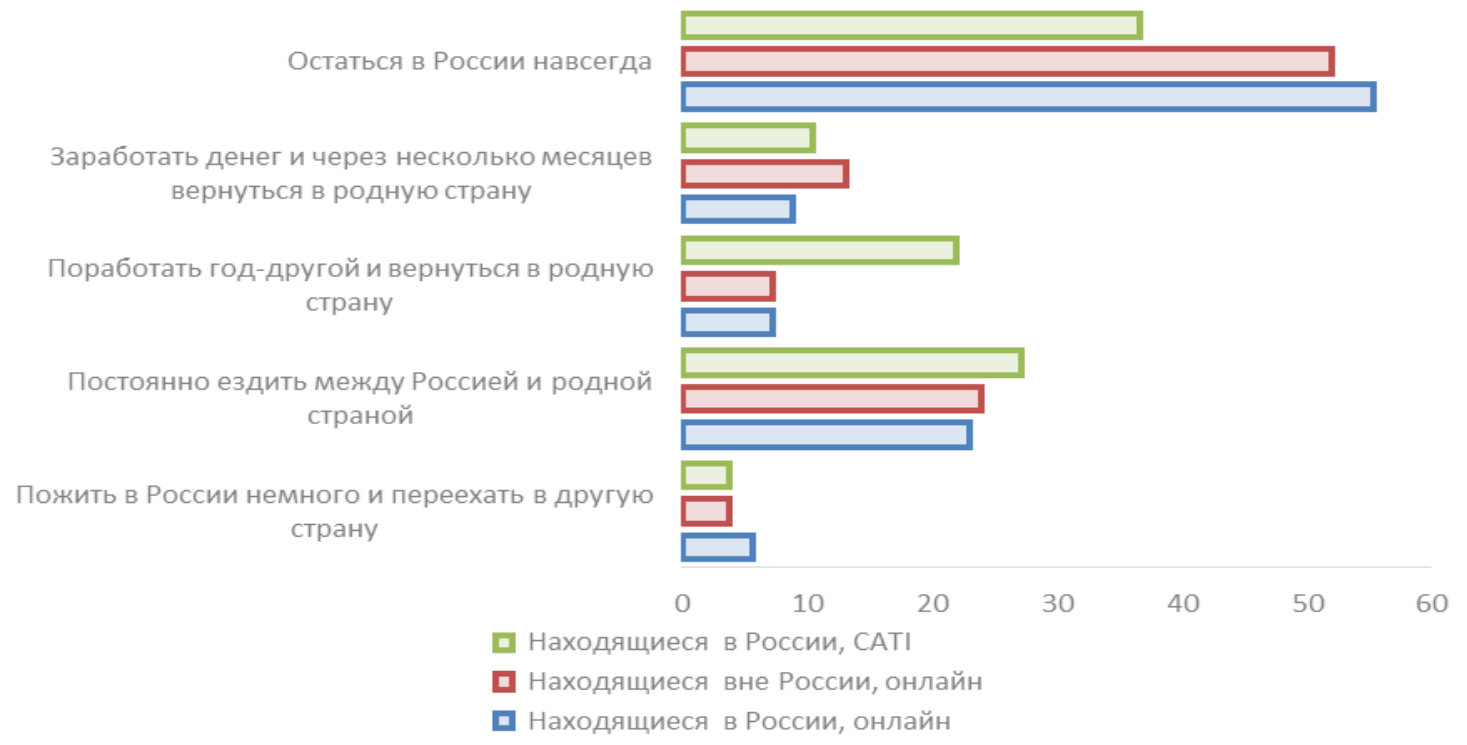

\section{Рисунок 6. Долгосрочные миграционные планы респондентов, \% ответивших}

Если посмотреть на планы респондентов относительно своего будущего, то более половины из них высказали намерение в конечном итоге остаться в России навсегда. Такие планы не чужды и менее квалифицированным работникам из Средней Азии (CATI). Примечательно, что наибольшая доля таких респондентов среди находящихся за пределами России - среди опрошенных русских и азербайджанцев (чуть больше 66\%); наименьшая среди белорусов (22\%).

Интеграционные настроения значительной части мигрантов фиксируются во всех опросах. Нынешняя сложно прогнозируемая социально-экономическая и эпидемиологическая обстановка в России и посылающих странах может скорректировать долгосрочные планы выходцев из постсоветских государств и привести к росту числа тех из них, кто будет склоняться к циркулярным миграциям, позволяющим более гибко реагировать на уровень жизни и конъюнктуру рынка труда в странах происхождения и странах назначения. В то же время постковидная российская экономика будет нуждаться в мигрантах так же, как и в допандемическом прошлом.

\section{ЛИТЕРАТУРА}

Абашин С. (2020). Коронавирус и миграция. Фонд «Либеральная миссия», 10.04.2020.

URL: http://liberal.ru/migration/koronavirus-imigraciya?fbclid=IwAR0JowXAmBBiL1QJSK2I5cdbaeLrgp7kvdsxFK6LcEiCD9MwoIVS ZvztYWE

Гимпельсон В., Капелюшников Р. (2020). Карантинная экономика и рынок труда. ЭКОНС, 02.06.2020. URL: https://econs.online/articles/ekonomika/karantinnaya-ekonomika-i-rynoktruda/

ГУВМ МВД РФ, Главное управление по вопросам миграции МВД РФ (2020). Статистические сведения по миграционной ситуаџии. URL: https://мвд.pф/Deljatelnost/statistics/migracionnaya (данные загружены 01.09.2020). 
Малахов В.С., Мотин А.С. (2020). Влияние пандемии COVID-19 на миграционные процессы и миграционную политику в Европейском Союзе и в России. В В.С. Гуревич, С.М. Дробышевский, А.В. Колесников, В.А. Мау, С.Г. Синельникова-Мурылев (Ред.), Мониторинг экономической ситуации в России: тенденщиии и вызовы социальноэкономического развития, 17(119), июнь, 3 (сс. 1-42). Институт экономической политики имени Е.Т. Гайдара, Российская академия народного хозяйства и государственной службы при Президенте Российской Федерации. URL: https://www.ranepa.ru/documents/2020_17-119_June.pdf

Погребняк Е. (2020). Евразийская интеграция. Рuтм Азии, 06.05.2020. URL: https://www.ritmeurasia.org/news--2020-05-06--vo-vremja-pandemii-problema-smigrantami-ne-mogla-ne-obostritsja-48877

Полетаев Д. (2020). Миграционные последствия «идеального шторма»: каким будет влияние пандемии коронавируса на проблемы миграции? РCMД, 07.05.2020. URL: https://russiancouncil.ru/analytics-and-comments/analytics/migratsionnye-posledstviyaidealnogo-shtorma-kakim-budet-vliyanie-pandemii-koronavirusa-na-problemy/

Росстат (2020b). Социально-экономическое положение России: январь-апрель 2020 года. М.: Минэкономразвития России.

Росстат (2020а). Итоги выборочного наблюдения труда мигрантов в 2019 году. URL: https://www.gks.ru/itog_inspect

Рязанцев С.В. (2020). На международном уровне не решена проблема синхронизации действий. Научная Россия, 17.04.2020. URL: https://scientificrussia.ru/articles/idesh-vmagazin-a-lyudi-prosto-prosyat-dat-deneg

Флоринская Ю. (2020). Трудовая миграция в РФ на этапе закрытия границ. В В.С. Гуревич, С.М. Дробышевский, А.В. Колесников, В.А. Мау, С.Г. СинельниковаМурылев (Ред.), Мониторинг экономической ситуации в России: тенденции и вызовы сочиально-экономического развития, 17(119), июнь (сс. 14-19). Институт экономической политики имени Е.Т. Гайдара, Российская академия народного хозяйства и государственной службы при Президенте Российской Федерации. URL: http://www.iep.ru/files/text/crisis_monitoring/2020_7-109_April.pdf

HRW, Human Rights Watch (2020). COVID-19 фактор роста расизма и ксенофобии 8 отночении выходиев из Азии. 12.05.2020. URL: https://www.hrw.org/ru/news/2020/05/12/375044

ILO, International Labor Organization (2020). Protecting migrant workers during the COVID-19 pandemic Recommendations for Policymakers and Constituents. Policy Brief, April. URL: https://www.ilo.org/wcmsp5/groups/public/---ed_protect/---protrav/--migrant/documents/publication/wcms_743268.pdf

OECD (2020). Managing international migration under COVID-19. 10.06.2020. URL: https://read.oecd-ilibrary.org/view/?ref=134_134314-9shbokosu5\&title=Managinginternational-migration-under-COVID-19

The World Bank (2020a). COVID-19 Crisis through a Migration Lens. Migration and Development, Brief 32, April. URL:

https://www.worldbank.org/en/topic/socialprotection/publication/covid-19-crisis-through-amigration-lens

The World Bank (2020b). Migration and Remittances Data. URL:

https://www.worldbank.org/en/topic/migrationremittancesdiasporaissues/brief/migrationremittances-data 


\title{
LABOUR MIGRATION IN RUSSIA DURING THE CORONAVIRUS PANDEMIC
}

\author{
MIKHAIL DENISENKO, VLADIMIR MUKOMEL
}

\begin{abstract}
Quarantine measures in connection with the coronavirus pandemic have been accompanied by the closure of cross-border communications and restrictions on the activities of enterprises in most sectors of the economy. Labour migrants and their family members staying in Russia have found themselves in a difficult situation. The reduction in employment, primarily in areas where migrants work, has made foreign citizens one of the most vulnerable social groups. The first layer of questions discussed in the article is related to the assessment of the situation of migrants in Russia. In what types of economic activity has the decline in employment become particularly painful for migrants? What is their financial situation? How ready are they to leave Russia if transport links are restored? What are their immediate and long-term plans related to work and life in Russia? The second focus of the study is on potential migrants who were unable to enter Russia after international transport links were severed. What is their economic situation at home? How quickly will they go to Russia when restrictions on international travel are removed? What are their short - and longterm plans for staying in Russia? This article is based on an online survey of 2,695 foreign citizens (including 1,304 migrants in Russia and 1,391 outside Russia), as well as a telephone survey of 300 migrant workers in the Moscow megalopolis conducted in the first half of June 2020.
\end{abstract}

Key words: labour migration, migrants, COVID-19, foreign workers, online survey, CATI, employment, migration intentions.

\begin{abstract}
MiKhail Denisenko (mdenissenko@hse.ru), NATIONAl RESEARCh University Higher SchoOl OF EcONOMICS, RUSSIA.

Vladimir MuKomel (mukomel@mail.ru), InstituTe of Sociology of FEDERAL Centre of Theoretical AND APPLIED SOCIOLOGY OF THE RUSSIAN ACADEMY OF SCIENCES, RUSSIA.

THE ONLINE SURVEY WAS IMPLEMENTED WITH THE SUPPORT OF THE NRU HSE DIRECTORATE FOR EXPERT ANALYSIS WITHIN THE FRAMEWORK OF THE NRU HSE APPLIED RESEARCH PROJECT TZ-125: "SYSTEMATIZATION OF WAYS TO ACHIEVE NATIONAL GOALS FOR ENSURING SUSTAINABLE NATURAL POPULATION GROWTH IN THE RUSSIAN FEDERATION AND INCREASING LIFE EXPECTANCY TO 78 YEARS (UP TO 80 YEARS BY 2030)". THE CATI SURVEY WAS CONDUCTED WITHIN THE FRAMEWORK OF THE NRU HSE TZ-151 PROJECT "ANALYSIS OF RISKS OF SOCIAL TENSION AND PROPOSALS FOR POLICY MEASURES AIMED AT IMPROVING SOCIAL SUSTAINABILITY".
\end{abstract}

DATE RECEIVED : JULY 2020.

\section{REFERENCES}

Abashin S. (2020). Koronavirus i migratsiya [Coronavirus and migration]. Fond "Liberalnaya missiya", 10.04.2020. (In Russ.) Retrieved from URL:

http://liberal.ru/migration/koronavirus-imigraciya?fbclid=IwAR0JowXAmBBiL1QJSK2I5cdbaeLrgp7kvdsxFK6LcEiCD9MwoIVS ZvZtYWE

Florinskaya J. (2020). Trudovaya migratsiya v RF na etape zakrytiya granits [Labour migration in the Russian Federation at the stage of border closure]. In V.S.Gurvich, S.M.Drobyshevskiy, A.V.Kolesnikov, V.A.Mau, S.G. Sinelnikov-Murylev (Eds.), Monitoring ekonomicheskoy situatsii v Rossii: tendentsii $i$ vyzovy sotsialno-ekonomicheskogo razvitiya, 17(119), June (pp. 14-19) [Monitoring the economic situation in Russia: trends and challenges of socio-economic development]. Gaidar Institute for Economic Policy, The 
Russian Presidential Academy of National Economy and Public Administration. (In Russ.) Retrieved from http://www.iep.ru/files/text/crisis_monitoring/2020_7-109_April.pdf

Gimpelson V., Kapelyushnikov R. (2020). Karantinnaya economika i rynok truda [Quarantine economics and labour market. ECONS, 02.06.2020. (In Russ.) Retrieved from https://econs.online/articles/ekonomika/karantinnaya-ekonomika-i-rynok-truda/

GUVM MVD RF, Main Directorate for migration (2020). Statisticheskiye svedeniya po migratsionnoiy situatsii [Statistical data on migration situation]. (In Russ.) (data downloaded 01.09.2020). URL: https://мвд.pф/Deljatelnost/statistics/migracionnaya

HRW, Human Rights Watch (2020). COVID-19 Fueling Anti-Asian Racism and Xenophobia Worldwide. 12.05.2020. URL: https://www.hrw.org/ru/news/2020/05/12/375044

ILO, International Labor Organization (2020). Protecting migrant workers during the COVID-19 pandemic Recommendations for Policymakers and Constituents. Policy Brief, April. URL: https://www.ilo.org/wcmsp5/groups/public/---ed_protect/---protrav/--migrant/documents/publication/wcms_743268.pdf

Malakhov V.S., Motin A.S. (2020). Vliyanie pandemii COVID-19 na migratsionnyie protsessy i migratsionnuyu politiku v Evropeiskom soyuze i v Rossii [The impact of the COVID-19 pandemic on migration processes and migration policy in the European Union and Russia]. In V.S.Gurvich, S.M.Drobyshevskiy, A.V.Kolesnikov, V.A.Mau, S.G. Sinelnikov-Murylev (Eds.), Monitoring ekonomicheskoy situatsii v Rossii: tendentsii i vyzovy sotsialnoekonomicheskogo razvitiya [Monitoring the economic situation in Russia: trends and challenges of socio-economic development]., 17(119), June (pp.31-42). Gaidar Institute for Economic Policy, The Russian Presidential Academy of National Economy and Public Administration. (In Russ.) Retrieved from https://www.ranepa.ru/documents/2020_17119_June.pdf

OECD (2020). Managing international migration under COVID-19. 10.06.2020. URL: https://read.oecd-ilibrary.org/view/?ref=134_134314-9shbokosu5\&title=Managinginternational-migration-under-COVID-19

Pogrebnyak E. (2020). Evraziyskaya integratsiya [Eurasian integration]. Ritm Evrasii, 06.05.2020. (In Russ.). Retrieved from https://www.ritmeurasia.org/news--2020-05-06--vovremja-pandemii-problema-s-migrantami-ne-mogla-ne-obostritsja-48877

Poletaev D. (2020). Migratsionnyye posledstviya «ideal'nogo shtorma»: kakim budet vliyaniye pandemii koronavirusa na problemy migratsii? [Migration Consequences of the "Perfect Storm": What Effect Will the Coronavirus Pandemic Have on Migration Issues?]. RIAC, 07.05.2020. (In Russ.). Retrieved from https://russiancouncil.ru/en/analytics-andcomments/analytics/migration-consequences-of-the-perfect-storm-what-effect-will-thecoronavirus-pandemic-have-on-migrat/?sphrase_id=51028638

Rosstat (2020a). Itogi vyborochnogo nablyudeniya truda migrantov $v 2019$ godu [Results of migrant labour monitoring survey in 2019]. (In Russ.). Retrieved from https://www.gks.ru/itog_inspect

Rosstat (2020b). Sotsialno-economicheskoie polozhenie Rossii: yanvar-aprel 2020 goda [Socialeconomic situation of Russia: April-May 2020]. Moscow: Ministry of Economic Development of Russia. (In Russ.).

Ryazantsev S.V. (2020). Na mezhdunarodnom urovnie nie reshena problema sinkhronizatsii dieystviy [The problem of synchronizing activities has not been solved at the international level]. Nauchnaya Rossia, 17.04.2020. (In Russ.) Retrieved form https://scientificrussia.ru/articles/idesh-v-magazin-a-lyudi-prosto-prosyat-dat-deneg 
The World Bank (2020a). COVID-19 Crisis through a Migration Lens. Migration and Development, Brief 32, April. URL:

https://www.worldbank.org/en/topic/socialprotection/publication/covid-19-crisis-through-amigration-lens

The World Bank (2020b). Migration and Remittances Data. URL:

https://www.worldbank.org/en/topic/migrationremittancesdiasporaissues/brief/migrationremittances-data 